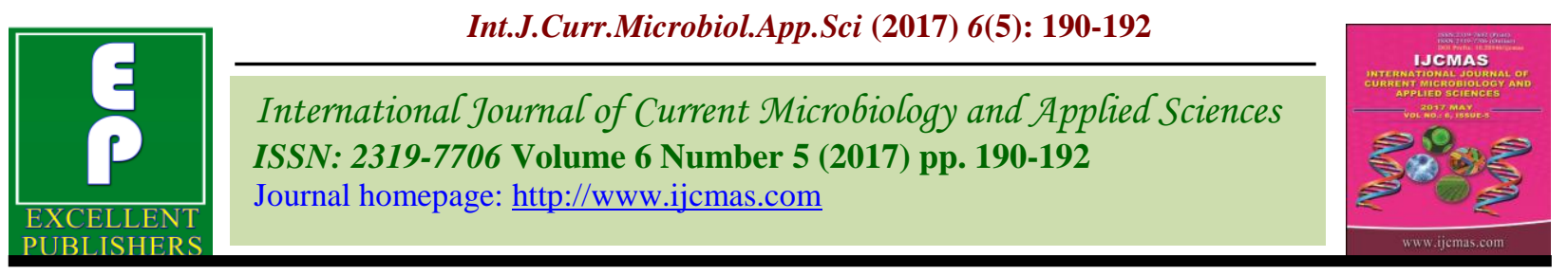

Case Study

https://doi.org/10.20546/ijcmas.2017.605.022

\title{
A Unique Case of Deg Nala Disease in Gir Cow and its Therapeutic Management
}

\author{
J.B. Kathiriya ${ }^{1 *}$, K.B. Savaliya ${ }^{2}$, A.R. Ahlawat ${ }^{3}$, S.N. Godasara ${ }^{4}$ and J.S. Patel $^{5}$ \\ ${ }^{1}$ Department of Veterinary Public Health and Epidemiology, Veterinary College, J.A.U., \\ Junagadh - 362001, Gujarat, India \\ ${ }^{2}$ Department of Polytechnics, Veterinary College, J.A.U., Junagadh - 362001, Gujarat, India \\ ${ }^{3}$ Department of Animal Genetics, Veterinary College, J.A.U., Junagadh - 362001, Gujarat, India \\ ${ }^{4}$ Department of Veterinary Microbiology, Veterinary College, J.A.U, \\ Junagadh - 362001, Gujarat, India \\ ${ }^{5}$ Department of Veterinary Medicine, Veterinary College, J.A.U, \\ Junagadh - 362001, Gujarat, India \\ *Corresponding author
}

\begin{tabular}{|c|c|}
\hline & A B S T R A C T \\
\hline $\begin{array}{l}\text { K e y w o r d s } \\
\text { Dag Nala } \\
\text { disease, Gir cow, } \\
\text { Therapeutic } \\
\text { management. }\end{array}$ & \multirow{3}{*}{$\begin{array}{l}\text { This disease is more prevalent in winter months mostly in the rice growing } \\
\text { parts of India. Mostly younger buffaloes are more frequently affected than } \\
\text { cattle. The disease cause general malaise, edema of the extremities, general } \\
\text { wasting with necrosis and sloughing of the epidermis. The possibilities of } \\
\text { mycotoxins produced from the wheat straw, dry grass or sorghum hay might } \\
\text { be the one of the reason for this condition. The condition is usually a febrile } \\
\text { and limits the movements of the affected animals due to painful condition of } \\
\text { the legs. Symptomatic therapeutic trial was carried out using antibiotics with } \\
\text { other supportive treatments and complete recovery was observed within } 45 \\
\text { days. }\end{array}$} \\
\hline Article Info & \\
\hline $\begin{array}{l}\text { Accepted: } \\
\text { 04 April } 2017 \\
\text { Available Online: } \\
10 \text { May } 2017\end{array}$ & \\
\hline
\end{tabular}

\section{Introduction}

Deg Nala disease, named due its first occurrence in the areas bordering the course of Deg Nala (Deg river), area of Pakistan in 1929-30 (Shirlow, 1939). This disease is more prevalent in winter months mostly in the rice growing parts of India like Bihar, Gujarat, Harana, Uttar Pradesh and West Bengal (Jadav and Mistry, 1997). Mostly these part of animals are raised on rice and wheat straw which are of poor nutritional quality, when such infected rice and wheat straw with Fusarium Fungus fed to these animals causes severe health problem, of these most common disease occurred among them is Deg Nala disease. This disease is characterized by general malaise, edema of the extremities, general wasting with necrosis and sloughing of the epidermis. The condition is usually a febrile and limits the movements of the affected animals due to painful condition of 
the legs (Shirlow, 1939; Irfan, 1971). Infections that may be debilitating in nature can cause significant economic losses as a result of decreased production confounded by reduced growth rate, mortality and poor animal performance. The present case reports a rare occurrence of Deg Nala disease in Gir cow.

\section{History and clinical observations}

A five year old female cow was presented at the Cattle Breeding Farm, J.A.U., Junagadh, Gujarat (India) with the history of lameness. On clinical observation, closely find with principle clinical signs of swelling of legs and then drying, necrosis and gangrenous lesion and sloughing of superficial skin on foot and reduction in milk production was observed. Clinical examination revealed normal rectal temperature, respiration rates and feeding and watering. On the basis of history and clinical observations case was tentatively diagnosed as Deg Nala disease.

\section{Treatment}

The cow was treated with the course of broad spectrum antibiotic oxytetracyclinLA@ $10 \mathrm{mg} / \mathrm{kg}$ body weight (TerramycineLA, pfizer) intramuscularly for three times at the interval of $72 \mathrm{hrs}$, along with this,

Fig.1 Cow with swelling of legs, dry, necrosis and gangrenous lesion

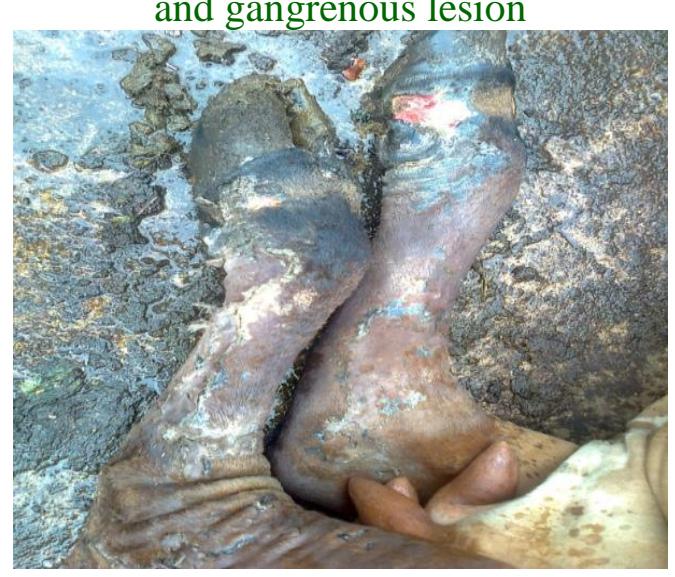

supportive treatment with anti-inflamatory drugs Nimesulide@ $4 \mathrm{mg} / \mathrm{kg}$ of body weight (Nimovet, IIL), injection of Vitamin AD3E@10ml and Antihistaminic@10ml (Avil, intervet) intramuscularly was administered for five consecutive days. After completion of this course of treatment, inj. Doramectin (Dectomax, Pfizer)@ 200 mcg/kg body weight subcutaneously was administered, simultaneously antiseptic dressing was carried out and the mixture of Nitrofurazone, Pendistrin SH cream, Negasunt, Zinc oxide, Copper sulphate powder was applied topically until animal was recovered.

\section{Results and Discussion}

The cow was successfully recovered completely by 45 days of treatment without affecting the milk production. Secondary bacterial infections of the lesions were responsible for the severity of the disease. One of the major cause of Deg Nala disease is by mycotoxin produced by the metabolism of Fusariam fungus grown on paddy/rice straw dissolves the collagen and elastin into collagenase and elastinase, respectively (Karki, 2012). As a result in the dependent parts of the ear, tail, foot blood supply is obstructed and ultimately tissue die of anoxia.

Fig.2 Cow recovered after complete treatment

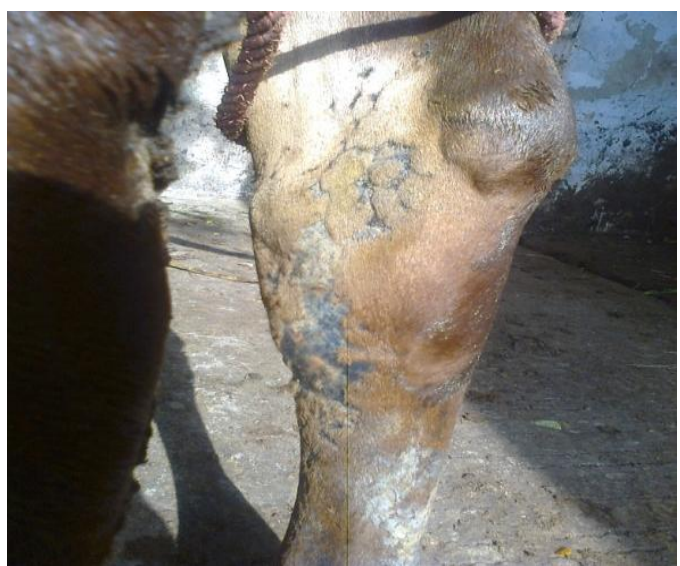


In present study the clinical symptoms and gross features of lesions recorded were in close conformity with the findings of earlier workers (Jadhav and Mistry et al., 1997, Sikdar et al., 2000 and Ifran, 1971). Loss of body weight in animals fed with infested straw could be due to anorexia and increase tissue catabolism (Fig. 1).

The occurrence of this disease in this part of Gujarat is very rare. During this case study there is no any evidence/history of feeding of paddy/rice straw to this animal and only single animal is affected. The feeding of infected wheat straw, dry grass or sorghum hay with Fusarium fungal might produced such mycotoxins in conducive environmental conditions like temperature, humidity and water content might be responsible for this condition. The cause of this condition is still matter of investigation.

The therapeutic treatment with long acting oxytetracycline was injected parentally to check secondary bacterial infection and antiinflammatory drugs was used to reduce the inflammatory condition. This was in a broad agreement with the findings of (Maqbool et $a l ., 1998)$ who found $70 \%$ cure rate with this treatment (Fig. 2).

Therapeutic trials with an antidote Antidegnala Liquor given orally and parentally gave highest percentage 90\% (Maqbool et al., 1998) cure rate whereas, Schoental (1980) who reported a cure rate of $80 \%$ with a penta-sulphate mixture.

\section{References}

Ifran, M. 1971. The clinical picture and pathology of Deg Nala disease in buffaloes. Vet. Rec., 88: 422- 424.

Jadhav, K.M., Mistry, J.N. 1997. A clinical record of spontaneous Deg Nala disease like disease in buffaloes in semi arid Banaskantha district of Gujurat state. Indian J. Vet. Res., 6: 32-6.

Kedar Karki. 2012. Why Degnala disease epidemic in buffaloes throughout South East Asia this year? http://en.engormix.com/MA-dairycattle/health/articles/degnala-diseaset2185/165-p0.htm

Maqbool, A., Khan, M. A., Yaqoob, M., Khan, I.A., Badar, N. Mahamood, F. 1998. Prevalence, etiology, chemotherapy and control of Deg Nala disease in buffaloes and cattle in Pakistan. Vet. Arch., 68: 213-217.

Schoental, R. 1980. Save your animals from Deg Nala disease. J. Nuclear Agri. Biol., 92: 27-28.

Shirlow, J.E. 1939. Deg Nala disease of buffaloes: An account of the lesions and essential pathology. Indian Vet. Sci. Anim. Husb., 9: 853-864.

Sikdar, A., Chakraborty, G.C., Bhattacharya, D., Bakshi, S., Basak, D.K. and Chatterjee, A., et al. 2000. An outbreak of gangrenous syndrome among buffaloes and cattle in West Bengal: clinicopathological studies. Trop. Anim. Health Prod., 32: 165-71.

\section{How to cite this article:}

Kathiriya, J.B., K.B. Savaliya, A.R. Ahlawat, S.N. Godasara and Patel, J.S. 2017. A Unique Case of Deg Nala Disease in Gir Cow and Its Therapeutic Management. Int.J.Curr.Microbiol.App.Sci. 6(5): 190-192. doi: http://dx.doi.org/10.20546/ijcmas.2017.605.022 